\title{
Time to pay attention to anemia in female adolescents
}

Jae Min Lee, MD, PhD

Department of Pediatrics, College of Medicine, Yeungnam University, Daegu, Korea
Anemia is a relatively common disease. According to the World Health Organization, between 1993 and 2005, about a quarter of the world's population had anemia, and it was more prevalent among preschool children and women. ${ }^{1)}$

In anemia, oxygen transport is impaired owing to a decrease in circulating red blood cells and, consequently, hemoglobin levels. Causes of anemia include hereditary hemolytic anemia, infection, and deficiencies in nutrients such as iron, vitamin B12, and folate.

In the 2000s, the worldwide prevalence of anemia decreased. This study investigated the change in the patterns of anemia in Korean adolescents from 1998 to 2018 using data from the Korea National Health and Nutrition Examination Survey. They found that the incidence of anemia in children 10-18 years of age in Korea is decreasing. Interestingly, among these adolescents with anemia, there were 9 times more females than males. In particular, the prevalence of anemia in women after menarche was 3.6-fold greater than that in women before menarche. In addition, their study confirmed that the prevalence of anemia slightly decreased with increasing body mass index and household income.

According to a Japanese study, the prevalence of anemia among healthy women $<50$ years old was $22.3 \%$, of which 25.2\% had severe anemia. ${ }^{2)}$ This suggested there is a need for increased interest in women's health.

The major causes of anemia in adolescents are summarized in
Table 1. Nutritional insufficiency, chronic blood loss, gastrointestinal disorder such as gastritis, infection, inflammatory bowel disease, and gynecological problem can cause anemia. Hemolysis due to red blood cell membranopathy, hemoglobinopathy, or enzymopathy can also cause anemia. Iron deficiency is the most important of the various causes of anemia. Menstruation is an important cause of blood loss, especially in adolescent females, and although iron intake is important, it is easy to overlook. Nutritional counseling and health management are crucial for school-age children. Campaigns or educational materials may be helpful in fulfilling these goals. In addition, if anemia persists, a pediatric hematologist should be consulted.

\section{Conflicts of interest}

No potential conflict of interest relevant to this article was reported.

See the article "Changes in the prevalence of anemia in Korean adolescents, 1998-2018” via https://doi.org/10.3345/cep.2020. 01508 .

\section{References}

1. McLean E, Cogswell M, Egli I, Wojdyla D, de Benoist B. Worldwide prevalence of anaemia, WHO Vitamin and Mineral Nutrition Information System, 1993-2005. Public Health Nutr 2009;12:444-54.

\section{Table 1. Factors contributing to anemia in adolescents}

\begin{tabular}{|c|c|}
\hline Causes & Reference \\
\hline Inadequate diet leading to an insufficient intake of nutrients such as iron, folic acid, vitamin B12, vitamin D, vitamin A & 3,4 \\
\hline Use of medications such as antacid, aspirin, and nonsteroidal anti-inflammatory drugs and foods that inhibit iron absorption & 3 \\
\hline Overweight and obesity lead to continuous inflammatory processes and aggravate anemia & 5 \\
\hline $\begin{array}{l}\text { Adolescent athletes comprise a larger proportion of those with iron deficiency anemia. This is caused by dilutional pseudoanemia, } \\
\text { intravascular hemolysis, and iron loss }\end{array}$ & $6-8$ \\
\hline $\begin{array}{l}\text { Malnutrition and inadequate diet associated with malabsorption syndrome, causing flattening or atrophy of the intestinal villi, thereby } \\
\text { aggravating micronutrient absorption }\end{array}$ & 9 \\
\hline Acute or chronic blood loss, injury, and blood donation & 3 \\
\hline $\begin{array}{l}\text { Gastrointestinal tract disorders such esophagitis, atrophic gastritis, colitis, Helicobacter pylori infection, inflammatory bowel disease, } \\
\text { diverticulosis, and hemorrhoids }\end{array}$ & 10 \\
\hline Menarche and menstrual abnormalities & 11 \\
\hline Hereditary hemolytic anemia & 12 \\
\hline
\end{tabular}

Corresponding author: Jae Min Lee, MD, PhD. Department of Pediatrics, Yeungnam University College of Medicine, 170 Hyeonchung-ro, Nam-gu, Daegu 42415, Korea 凶Email: mopic@hanmail.net, https://orcid.org/0000-0001-6822-1051

Received: 28 December, 2020, Revised: 17 January, 2021, Accepted: 19 January, 2021

This is an open-access article distributed under the terms of the Creative Commons Attribution Non-Commercial License (http://creativecommons.org/licenses/by$\mathrm{nc} / 4.0 /$ ) which permits unrestricted non-commercial use, distribution, and reproduction in any medium, provided the original work is properly cited.

Copyright @ 2021 by The Korean Pediatric Society 
2. Kusumi E, Shoji M, Endou S, Kishi Y, Shibata T, Murashige N, et al. Prevalence of anemia among healthy women in 2 metropolitan areas of Japan. Int J Hematol 2006;84:217-9.

3. Reeves JD, Yip R, Kiley VA, Dallman PR. Iron deficiency in infants: the influence of mild antecedent infection. J Pediatr 1984;105:874-9.

4. Kurpad AV, Edward BS, Aeberli I. Micronutrient supply and health outcomes in children. Curr Opin Clin Nutr Metab Care 2013;16:32838.

5. Nead KG, Halterman JS, Kaczorowski JM, Auinger P, Weitzman M. Overweight children and adolescents: a risk group for iron deficiency. Pediatrics 2004;114:104-8.

6. Olsson KS, Marsell R, Ritter B, Olander B, Akerblom A, Ostergard H, et al. Iron deficiency and iron overload in Swedish male adolescents. J Intern Med 1995;237:187-94.

7. Oski FA. Iron deficiency in infancy and childhood. N Engl J Med 1993; 329:190-3.

8. Soekarjo DD, de Pee S, Bloem MW, Tjiong R, Yip R, Schreurs WH, et al. Socio-economic status and puberty are the main factors determining anaemia in adolescent girls and boys in East Java, Indonesia. Eur J Clin
Nutr 2001;55:932-9.

9. Rockey DC. Occult gastrointestinal bleeding. Gastroenterol Clin North Am 2005;34:699-718.

10. Baker WF. Iron deficiency in pregnancy, obstetrics, and gynecology. Hematol Oncol Clin North Am 2000;14:1061.

11. Cho GJ, Park HT, Shin JH, Hur JY, Kim YT, Kim SH, et al. Age at menarche in a Korean population: secular trends and influencing factors. Eur J Pediatr 2010;169:89-94.

12. Shim YJ, Jung HL, Shin HY, Kang HJ, Choi JY, Hah JO, et al. Epidemiological study of hereditary hemolytic anemia in the Korean pediatric population during 1997-2016: a nationwide retrospective cohort study. J Korean Med Sci 2020;35:e279.

How to cite this article: Lee JM. Time to pay attention to anemia in female adolescents. Clin Exp Pediatr 2021;64:78-9. https://doi.org/10.3345/cep.2020.02117 